\title{
THE RELATIONSHIP BETWEEN EMPLOYEES ENGAGEMENT AND BUSINESS \\ PERFORMANCE: THE CASE OF ENTERPRISES IN PHU THO PROVINCE
}

\author{
Dr. Luu The Vinh \\ Faculty of Business and Administration, Hung Vuong University \\ Nong Trang Ward, Viet Tri City, Phu Tho Province, Vietnam
}

\begin{abstract}
Nowadays, in the global integration context, searching for ways to foster employee engagement within the organization to increase competitive advantage is mandatory for businesses to survive and develop sustainably. This paper analyzed the relationship between employee engagement and business performance, thereby, proposed governance implications for managers to create appropriate policies to improve operational efficiency in the coming time.
\end{abstract}

Key words: Loyalty, Employees engagement, Business performance, Phu Tho.

Cite this Article: Luu The Vinh, The Relationship between Employees Engagement and Business Performance: The Case of Enterprises in Phu Tho Province, International Journal of Management, 11(12), 2020, pp 763-771.

http://iaeme.com/Home/issue/IJM?Volume=11\&Issue=12

\section{INTRODUCTION}

In the era of the 4.0 revolution, the activities of economic, cultural, and trade exchanges between countries are changing and developing, the competition between businesses, between localities and countries is increasingly harsh. Therefore, businesses and organizations need to study new ways to improve their competitiveness in the direction of sustainable and stable development different from their competitors (Porter and Siggelkow, 2008). If in the past, the strategies that companies often used such as improving product quality, diversifying models, functions of products and services to improve competitiveness, today the issue of organizational engagement is very important to the leader of organizations, and as a key factor in determining employee work behavior. In particular, with the increase in both speed and size in organizational change, administrators are constantly searching for ways to foster closer employee engagement within the organization, thereby increasing competitive advantage (Lok and Crawford, 2001). Schuster (1998) mentions "an era in which organizations are 
constantly facing complex change, the employee's organizational attachment is seen as an extremely valuable resource. important to adapt quickly to changing demands".

$\mathrm{Phu}$ Tho is a province in the northern midlands and mountains of Vietnam, where has favorable natural and socio-economic conditions for economic development. However, the economy of Phu Tho still has many difficulties, not commensurate with its inherent potential. The reason is that the province has not had many favorable policies for economic development in general and the development of enterprises in particular. The whole province currently has more than 4701 businesses in operation, including 24 state-owned enterprises, 4552 non-state enterprises, and 125 foreign-invested enterprises, settling for more than 142,366 employees. However, more than $98 \%$ of them are small and micro enterprises, the competitiveness is weak, the economic efficiency is still low, about 53 enterprises are dissolved on average every year.

The article examines the relationship between employee engagement with business performance to find solutions to contribute to improve operational efficiency and enterprise competitiveness in Phu Tho province in the coming time.

\section{LITERATURE REVIEW}

\subsection{The Result of Enterprise Performance}

The result of enterprise performance and performance measurement is increasingly improved and have more important implications for businesses. According to Kaplan and Norton (1993), "The results of enterprises are determined from 04 basic groups of components, including finance, customers, internal processes and developmental learning. It builds the basis for transforming the content of the enterprise strategy into execution conditions". While Neely (1995) said that "The enterprise result is a set of criteria to quantify the efficiency and effectiveness of the operational aspects in enterprises. It is measured by 03 levels: individual, business goals, and the relationship between those evaluation criteria with the operating environment (culture, customer satisfaction, development strategy...). Otley (1999) argues that corporate performance "is the information intended to provide administrators who are tasked with maintaining and developing behavioral standards in corporate performance. Components include: goals, strategies, spending, rewards, and information flows". In addition, Maisel (2001) defines that "enterprise performance is the system that helps enterprises to plan, measure and control the results of sales, marketing, information technology, business decision making ... and other activities of the enterprise to set goals and create value for people with related interests". In a nutshell, enterprise performance is a system that measures the implementation of business goals in a period by financial and non-financial criteria. Thereby, it helps businesses have more information to fulfill their administration goals.

\subsection{Employee Engagement}

One of the most important definitions of employee engagement is that an employee identifies himself with the company and working to reach the objectives and aims of the company. According to Meyer and Allen (1997), the psychological manner of an employee affects his/her decisions about working. Employee commitment is a pattern of behavior in which an employee desires to be a permanent staff of the company and it is shaped based on the relationship of the employee with the company (Meyer and Allen 1997, 11). O'Reilley ve Chatman (1986) defined it as a psychological commitment of an individual towards the company. Employee engagement is the degree of adoption of the company and its objectives and, willingness to work in the company. It is the strength of the connection between the company and the employee. Other definitions of employee loyalty are as following; 
Accepting aims and objectives of the company, working for them, having a strong desire to increase the success of the company, and desiring to be a member of the company.

Identifying himself or herself with the company individually and working for the aims of the company. Yearning for being a member of the company and making an effort for the company by strongly accepting the aims and objectives of it. Employee engagement is "the relative strength of cohesion and whole-heartedness of an individual in a particular organization" (Mowday et al., 1979); being a positive relationship with the organization makes them always willing to invest their efforts to contribute to the success and development of the organization" (Kalleberg, 1996). "Employee's engagement is completely different from patiently submissive behavior which is a characteristic of traditional human resource management. Compliance maintained by the imposed control system leads to reactions, rather than positive and proactive behaviors at work. In contrast, engagement is built on faith and a work environment of mutual trust" (Legge, 1995).

Charles O.R. and Jennifer C. (1986) pointed out that engagement is the employee's attitude. Simultaneously, the authors found that organizational engagement is divided into three factors: compliance, identity, and acquisition. In which, compliance appears when attitudes and behaviors are accepted, not by beliefs, but simply to achieve a specific reward. Identity occurs when an individual proud of being a member of an organization, respecting the values and achievements of that organization without taking it as his or her achievement. Employees who are emotionally engaged with the organization will usually stay with the organization because they want. Employees who engage base on considering the interests of the individual with the organization will stay with the organization because they need it. And the employees who engage by responsibility will stay with the organization because they feel they have to do that (Meyer and Allen, 1991). And "the premise for employees to emotionally engage with the organization often classified into personal characteristics, work, work experience, and organizational characteristics. Personal feature refers to gender, age, education, marital status, job level, and working seniority. Job characteristics focus on diversity in types of working skills, autonomy in tasks, job challenges, and scope of work. Organizational characteristics include organizational policies, support, information and exchange, accreditation" (Mathieu and Zajac, 1990).

The loyalty of employees affects performances like the profitability of companies or labor loss. The motivation of employees is an inspirational factor that increases the will to work. If a company wants to motivate its employees successfully to realize its objectives, the first thing to do is to ensure loyalty. In other words, more loyal employees work more efficiently which leads up to produce better products and give better services. As a result, the satisfaction of employees increases.

\subsection{Role of Engagement in the Organization}

Engagement has great value in an organization. Ranya N (2009) emphasized that engagement had a strong impact on the performance and success of an organization. Because highly engaged employees define the goals and values of the organization, they had a strong desire to stay with the organization and willing to fulfill tasks that exceed the requirements of their superiors. . If human resources are considered an organization's assets, cohesive human resources are considered as a competitive advantage of the organization. The attachment increases employee satisfaction in the organization; improves the atmosphere in the organization in a positive direction; increases employee income; keep employees in the organization, promote team spirit in the organization; increase employee productivity; improve employee confidence in the organization contribute to the development of enterprises. 
It can be seen that engagement plays an important role in the success of an organization. Obviously, a company or organization can not achieve success and long-term goals without employees who believe in the company's mission and understand how to accomplish it. Therefore, the organization should focus on building a long-term working environment, helping the organization to adapt quickly to changes. When employees have faith and stick with the organization, they will have loyalty to trust the organization, the changes that organizations make are seen as necessary and they will have a more positive attitude.

\subsection{Measure Organizational Engagement}

According to Mowday et al. (1979), organizational engagement is a second-order concept measured by three components: Identification; Loyalty, and Involvement. In which: Identification shows a strong belief and acceptance of the organization's goals and values. Loyalty expresses a desire to remain a long-term member of the organization. Involvement shows their best efforts for the existence and development of the same organization.

According to Allen and Meyer (2004), organizational attachment is a second-order concept measured by three components: Affective commitment; Normative; Continuance. In which: The Affective Commitment Scale is a feeling of attachment, the desire to be involved in the organization. In other words, it is the desire to be a member of the organization. The Continuance Commitment Scale is the willingness to work hard; is the employee found to lose "cost" when leaving the organization. The Normative Commitment Scale feels like a requirement and must engage with the organization. That means businesses need to try to create emotional cohesion among their employees, in order to ensure the longest employee retention.

Tran Kim Dung (2009) assumed The influence of leadership and organizational culture on employee performance and loyalty to the organization proposed a conceptual scale of organizational cohesion of 3 Ingredients: Effort; Loyalty and Pride. In which: Effort is the employee's best effort to devote more to the organization and at the same time willing to sacrifice personal interests when necessary for the success of the organization. Loyalty is the employee's intention to stay in the long term with the organization, although other places offer a relatively more attractive salary and bonus. Pride is the employees proud of wearing the organization's flag colors; consider the organization as a second home, and at the same time think that it is the best workplace and living environment that everyone should aim for.

Organizational commitment is the employee's perception of their organization, which is an important factor in their working attitude (Mowday et al., 1982). Organizational engagement reflects the employee's relationship with an organization and influences the decision to maintain permanent employment with the organization (Meyer and Allen, 1997). Employees join organizations because of individual needs, desire to hone their skills and expectations. They hope to work in an environment where they can use their capabilities to meet the needs of the organization. If an organization provides opportunities for workers, the degree of employee commitment to the organization may increase (Vakola and Nikolaou, 2005).

\section{RESEARCH METHODOLOGY}

This study was conducted in enterprises with $100 \%$ foreign capital and domestic private enterprises. These are the two types of enterprises with large numbers in Phu Tho. The author conducted to test the reliability of the scale by testing Cronbach's Alpha for each group of factors after EFA analysis. Thereby, it allows the elimination of inappropriate variables in the research model. According to Hoang Trong and Chu Nguyen Mong Ngoc (2008), Cronbach's Alpha coefficients from 0.8 to nearly 1 will be a good scale, from 0.7 to 0.8 is usable. The usable scale must have a Corrected Item - Total Correlation above 0.3 (Hair et al., 2010). In 
the process of Cronbach's Alpha, the author will retain the scales with Cronbach's Alpha values $\geq 0.7$ and the type of observed variables with total variable correlation $<0.3$. The scale is developed from the form of a five-level Likert scale from 1-5 (1 completely disagrees; to 5 is completely agree)

\section{RESULTS AND DISCUSSION}

\subsection{Description Sample}

Regarding the type of enterprises, included $32.3 \%$ were foreign-invested enterprises, and $67.7 \%$ domestic private enterprises. Regarding capital sources, the results of the analysis showed that enterprises with up to $94.7 \%$ of enterprises were small and micro-enterprises, with a capital of less than 3 billion VND. Enterprises with a capital of more than 3 billion VND was only $5.3 \%$ (most of them are foreign-invested enterprises). In terms of the number of employees, accounting for the highest proportion are enterprises with 50 to fewer than 200 people were $52.5 \%$; enterprises with less than 50 people were $22.3 \%$, businesses with 200 500 people occupied $21,4 \%$, and the lowest proportion is over 500 people were $3.8 \%$. Regarding industries, accounting for the highest proportion were enterprises in the garment industry with $46.6 \%$, industrial production was $27.6 \%$; the service enterprises with $18.3 \%$ and enterprises in other sectors account for $7.5 \%$.

Table 1 Description Sample

\begin{tabular}{|c|c|c|}
\hline Criteria & Quantity & Ration (\%) \\
\hline \multicolumn{3}{|l|}{ Kind of enterprises } \\
\hline Foreign-invested enterprises & 129 & 32.3 \\
\hline Domestic enterprises & 270 & 67.7 \\
\hline \multicolumn{3}{|c|}{ Capital scale } \\
\hline Under 1 billion VNĐ & 120 & 30.0 \\
\hline From 1 billion - under 3 billion VNĐ & 258 & 64.7 \\
\hline Above 3 billion VNĐ & 21 & 5.3 \\
\hline \multicolumn{3}{|c|}{ Industry } \\
\hline Service & 73 & 18.3 \\
\hline Garment & 186 & 46.6 \\
\hline Industry & 110 & 27.6 \\
\hline Other & 30 & 7.5 \\
\hline
\end{tabular}

Sources: Analysis results, 2019

\subsection{Results of Inspection of Scales}

The result of the inspection the Scale of affective commitment with 5 items; The maintaining commitment scale has 6 items; Scale of moral commitment has 6 items; and the Scale of enterprise performance has 5 items showed that all of the items have Cronbach's Alpha higher 0.7 and the Variable - total adjusted correlation coefficient of all observed variables are above 0.3 , so all these variables are kept for use in the EFA analysis in the next.

Table 2 Reliability Statistics

\begin{tabular}{|l|c|c|}
\hline \multicolumn{1}{|c|}{ Scale } & Cronbach's Alpha & N of Items \\
\hline Affective commitment (AC) & .926 & 5 \\
\hline Continuance commitment (CC) & .854 & 5 \\
\hline Moral commitment (MC) & .832 & 4 \\
\hline Enterprise performance (EP) & .785 & 5 \\
\hline
\end{tabular}

Source: Author's survey results, 2019 


\subsection{Discuss Commitment Factors}

Affective commitment $(A C)$ : The survey results showed that commitment has a strong impact on the business results of enterprises. However, the scale of affective commitment is underestimated, in which, the scale "Enterprise is very important to you" is evaluated quite low with an average score of 3.23. In general, businesses have not cared about their employees. In each organization there are individuals with different characteristics, so the care cannot be general, there must be specific ways of care, sometimes just a birthday greeting, or a special event, will significantly increase employee's affection for the organization. A working environment that makes employees feel happy; people are willing to meet and help each other, thereby creating a positive culture for the company.

Leadership style; communication between management and employees also contribute significantly to a positive or negative atmosphere. A proper top-down, bottom-up, or peer-topeer communication are effective ways of enhancing employee engagement if we could make good use of it. Employees feel that they are being concerned, listened to, shared, motivated, and helped, which will foster a positive employee and organizational relationship. Besides, businesses need to have activities to reinforce external relationships such as organizing cultural exchanges, sports to unite everyone, thereby not only affecting emotions but also affecting the effectiveness of teamwork among employees.

Table 3 The statistical results describe the scale of affective commitment

\begin{tabular}{|c|l|c|c|c|c|}
\hline Encode & \multicolumn{1}{|c|}{ Items } & Minimum & Maximum & Mean & $\begin{array}{c}\text { Std. } \\
\text { Deviation }\end{array}$ \\
\hline AC1 & You are proud of working in the enterprise & 1 & 5 & 3.34 & 1.124 \\
\hline AC2 & Enterprise is very important to you & 1 & 5 & 3.23 & 1.105 \\
\hline AC3 & Do you see the enterprise as your second family? & 1 & 5 & 3.26 & 1.118 \\
\hline AC4 & $\begin{array}{l}\text { You feel that the difficult problems of the enterprise } \\
\text { are also your problems }\end{array}$ & 1 & 5 & 3.35 & 1.146 \\
\hline AC5 & Do you feel that you belong to the enterprise? & 1 & 5 & 3.36 & 1.024 \\
\hline
\end{tabular}

Source: Author's survey results, 2019

Continuance Commitment (CC): In general, this factor was rated at the highest score among the factors were evaluated with the average score was 3.986. In which, the items "Staying with your business now is necessary for you" and "Although you want to, you feel that leaving the enterprise now is difficult for you" were highly appreciated, in turn of 4.16 and 4.12 points. This showed that the employees highly appreciated the continuance commitment items because they feel financial loss if they no longer stay with the organization. Therefore, businesses need to have reasonable remuneration policies, and employee assessment must be fair and accurate. Simultaneously, resolving the employees' complaints quickly and promptly, avoiding dissatisfaction because of inadequate and inadequate resolution.

Table 4 Thee statistical results describe the scale of continuance commitment

\begin{tabular}{|c|l|c|c|c|c|}
\hline Encode & \multicolumn{1}{|c|}{ Items } & Minimum & Maximum & Mean & $\begin{array}{c}\text { Std. } \\
\text { Deviation }\end{array}$ \\
\hline CC 1 & Staying with the enterprise is essential for you now & 1 & 5 & 4,16 & 0,864 \\
\hline CC 2 & $\begin{array}{l}\text { You feel that leaving the enterprise at this time is difficult for } \\
\text { you. }\end{array}$ & 1 & 5 & 4,12 & 0,830 \\
\hline CC 3 & Your life will be affected a lot if you leave the enterprise now & 1 & 5 & 3,83 & 0,913 \\
\hline CC 4 & $\begin{array}{l}\text { If you didn't invest a lot in the enterprise, you might have quit } \\
\text { your job }\end{array}$ & 1 & 5 & 3,96 & 0,974 \\
\hline CC 5 & If you leave the enterprise, it is hard to find the same jobs & 1 & 5 & 3,85 & 0,850 \\
\hline
\end{tabular}

Source: Author's survey results, 2019 
Normative commitment (NC): Labor in enterprises had a short working experience so the stickiness is weak. They are willing to change jobs if there are better working conditions, as well as better treatment of the new workplace. However, the items "The enterprise has brought you a lot of things, you feel that you are indebted to the enterprise" was rated the highest with an average score of 3.59. This shows that this is one of the important factors to help retain employees in enterprises.

Table 5: The statistical results describe the scale of normative commitment

\begin{tabular}{|l|l|l|l|l|l|}
\hline Encode & \multicolumn{1}{|c|}{ Items } & Minimum & Maximum & Mean & $\begin{array}{c}\text { Std. } \\
\text { Deviation }\end{array}$ \\
\hline $\mathrm{NC} 1$ & You feel a responsibility to stay with the enterprise & 1 & 5 & 3,56 & 0,828 \\
\hline $\mathrm{NC} 2$ & You feel guilty if you leave the enterprise now & 1 & 5 & 3,48 & 0,811 \\
\hline $\mathrm{NC} 3$ & The enterprise deserves your loyalty & 1 & 5 & 3,52 & 0,796 \\
\hline $\mathrm{NC} 4$ & $\begin{array}{l}\text { The enterprise has brought you a lot of things, you feel that } \\
\text { you are indebted to the enterprise }\end{array}$ & 1 & 5 & 3,59 & 0,808 \\
\hline
\end{tabular}

Source: Author's survey results, 2019

\subsection{Discuss Business Performance}

In general, the performance of enterprises in Phu Tho was quite good. The employees highly evaluated two factors: increasing sales and profits in recent years. However, the market share has not been evaluated well, under the competition in the market economy, the market share of these enterprises was quite limited.

Table 6 Statistical results of enterprises performance

\begin{tabular}{|c|l|c|c|c|c|}
\hline Encode & \multicolumn{1}{|c|}{ Items } & Minimum & Maximum & Mean & $\begin{array}{c}\text { Std. } \\
\text { Deviation }\end{array}$ \\
\hline EP1 & Sales increased & 2 & 5 & 3,72 & 0,594 \\
\hline EP2 & Profit increased & 2 & 5 & 3,68 & 0,615 \\
\hline EP3 & Market share increased & 2 & 5 & 3,62 & 0,621 \\
\hline EP4 & The number of new customers increased & 2 & 5 & 3,69 & 0,594 \\
\hline EP5 & $\begin{array}{l}\text { The number of customers satisfied with the } \\
\text { enterprise increased }\end{array}$ & 2 & 5 & 3,67 & 0,618 \\
\hline
\end{tabular}

Sources: Analysis results, 2019

\subsection{Governance Implications}

Organizational engagement is the employee's perception of their organization, which is an important factor in their working attitude (Mowday et al., 1982). Organizational engagement reflects the employee's relationship with an organization and influences the decision to maintain permanent employment with the organization (Meyer and Allen, 1997). Employees join organizations because of several individual needs, a desire to hone their skills and expectations. They hope to work in an environment where they can use their capabilities to meet the needs of the organization. If an organization creates opportunities for its employees, the employee's level of organizational commitment can increase (Vakola and Nikolaou, 2005). Lawler (1969) emphasized: The basic motivation from the job as well as the degree of engagement depends on the way of operating, in which the employees have the right to give feedback and freedom in using their abilities. The higher the employee's attachment to the enterprise, the lower the rate of staff change, which will help the company attract and retain experienced talent, as well as becomes a premise for the sustainable development of businesses in their existing industries. Hence, businesses need to pay attention to manage 
through their respective work performance corresponds to each position to increase engagement.

The first is to build engagement by improving the work environment: developing a work environment that promotes a positive work attitude, creates excitement and enthusiasm at work, and reduces the pressure. Focus on communication style within the company, inclusion, creating good relationships among employees, treating everyone fairly, respecting their contributions, respecting their opinions, and give them a chance to grow.

The second is to create attachment by creating individual growth opportunities: building a corporate culture that favors learning and layout clear methods to ensure that employees are given opportunities and encouraged to learn and progress at work. The key line is that opportunities must be given to everyone, do not underestimate anyone's abilities. Accordingly, people should be managed through their performance and ability to progress, no matter who they are.

The third is to create engagement for employees by empowering the right to participate: Enabling each person to participate effectively in the work is not simply through consultation and consultation, though it is necessary. The important thing is to create a working environment where everyone is facilitated to execute ideas and overall, all management members must know how to listen and appreciate the closure contribution from staff.

\section{CONCLUSION}

This paper analyzed the relationship between employee engagement and business performance, thereby, proposed governance implications for managers to create appropriate policies to improve operational efficiency in the coming time.

\section{REFERENCES}

[1] Brammer, S., Millington, A., \& Rayton, B. (2007), "The contribution of corporate social responsibility to organizational commitment", The International Journal of Human Resource Management, 18(10), 1701- 1719.

[2] Charles, O. R., \& Jennifer, C. (1986), "Organizational commitment and psychological attachment: The effects of compliance, identification, and internalization on prosocial behavior", Journal of applied psychology, 71(3), 492.

[3] Hoang Trong \& Chu Nguyen Mong Ngoc (2008), 'Research data analysis with SPSS', Hong Duc Publishing House.

[4] Kaplan, R. S., \& Norton, D. P. (1993)," Implementing the balanced scorecard at FMC corporation: An interview with Larry D. Brady", Harvard Business Review, 71(5), 143-7.

[5] Kalleberg, A. L. (Ed.). (1996), Organizations in America: Analysing their structures and human resource practices, Sage.

[6] Legge, K. (1995), “What is human resource management?", In Human resource management (pp. 62-95), Palgrave, London

[7] Lok, P., \& Crawford, J. (2001), "Antecedents of organizational commitment and the mediating role of job satisfaction", Journal of managerial psychology, 16(8), 594-613

[8] Maisel, L. S. (2001), Performance measurement practices survey results, Ewing, NJ: American Institute of Certified Public Accountants.

[9] Meyer, J. P., Allen, N. J., \& Smith, C. A. (1993), "Commitment to organizations and occupations: Extension and test of a three-component conceptualization", Journal of applied psychology, 78(4), 538. 
[10] Meyer, J. P., \& Allen, N. J. (1991), “A three-component conceptualization of organizational commitment", Human resource management review, 1(1), 61-89.

[11] Meyer, J. P., \& Allen, N. J. (2004), TCM employee commitment survey academic users guide 2004, London, Ontario, Canada: The University of Western Ontario, Department of Psychology.

[12] Meyer, J. P., Allen, N. J., \& Allen, N. J. (1997), Commitment in the workplace, Sage Publications.

[13] Meyer, J. P., Allen, N. J., \& Smith, C. A. (1993), "Commitment to organizations and occupations: Extension and test of a three-component conceptualization", Journal of applied psychology, 78(4), 538.

[14] Mowday, R. T., Porter, L. W., \& Steers, R. (1982), "Organizational linkage: the psychology of commitment, absenteeism, and turnover", New York, NY.: Academic Press. NHS Information center (2008). Statistics/Data Collections-Prescriptions, available from www. ic. nhs. UK. Accessed, 10(3), 2008.

[15] Mathieu, J. E., \& Zajac, D. M. (1990), "A review and meta-analysis of the antecedents, correlates, and consequences of organizational commitment", Psychological Bulletin, 108(2), 171.

[16] Mowday, R. T., Steers, R. M., \& Porter, L. W. (1979), “The measurement of organizational commitment", Journal of vocational behavior, 14(2), 224- 247.

[17] Neely, A., Gregory, M., \& Platts, K. (1995), "Performance measurement system design: a literature review and research agenda", International journal of operations \& production management, 15(4), 80-116.

[18] Otley, D. (1999), "Performance management: a framework for management control systems research", Management accounting research, 10(4), 363- 382.

[19] O'Reilly, C. A., \& Chatman, J. (1986), "Organizational commitment and psychological attachment: The effects of compliance, identification, and internalization on prosocial behavior", Journal of applied psychology, 71(3), 492.

[20] Porter, M., \& Siggelkow, N. (2008), "Contextuality within activity systems and sustainability of competitive advantage", The Academy of Management Perspectives, 22(2), 34-56.

[21] Phu Tho Statistical Office (2019), Statistical Handbook of Phu Tho 2019,

[22] Ranya N. (2009), "What is the organizational commitment, why should managers want it in their workforce and is there any cost-effective way to secure it", Swiss Management Center (SMC) working paper retrieved at www. swiss $m s$.

[23] Schuster FE (1998), "A strategy for high commitment and involvement: Employee centered management', London Express: Quorum.

[24] socongthuong.phutho.gov.vn/statistic/detail/393/tinh-hinh-kinh-te-xa-hoi-nam-2019-tren-diaban-tinh-phu-tho

[25] Vakola, M., \& Nikolaou, I. (2005), “Attitudes towards organizational change: What is the role of employees' stress and commitment?”, Employee Relations, 27(2), 160-174.

[26] Tran Kim Dung (2009), "The influence of leadership and organizational culture on employee performance and organizational loyalty", Economic Development, No. 227, pp. 2-10. 